\title{
Trading on Preconceptions
}

\author{
Why World War I Was Not a Failure of \\ Economic Interdependence
}

The relationship between economic interdependence and military conflict is among the most studied and debated in the international relations literature. Scholars who argue that economic ties reduce the likelihood of conflict have struggled to reconcile this view with the outbreak of World War I. The conventional wisdom among political scientists is that World War I constituted a failure of economic integration to maintain peace. ${ }^{1}$ Even prominent advocates of liberal theory view World War I as an unfortunate contradiction to the general argument that trade inhibits conflict. ${ }^{2}$

These arguments are important for several reasons. First, they bear on scholars' understanding of the causes of war and peace and on more pragmatic issues of policy in an increasingly globalized, but still fractious, world. Whether interdependence encourages states to resolve differences diplomatically or not

Erik Gartzke is Associate Professor of Political Science and Yonatan Lupu is a Ph.D. candidate in political science, both at the University of California, San Diego. The authors contributed equally to this article, and their names are listed alphabetically.

The authors wish to thank Mariano Bertucci, Chris Fariss, Eric Hamilton, Jack Levy, Keir Lieber, Norrin Ripsman, Arthur Stein, William Wohlforth, and the anonymous reviewers for helpful comments and suggestions.

1. Kenneth N. Waltz, Theory of International Politics (New York: McGraw-Hill, 1979); Barry Buzan, "Economic Structure and International Security: The Limits of the Liberal Case," International Organization, Vol. 38, No. 4 (Autumn 1984), pp. 597-624; Dale C. Copeland, "Economic Interdependence and War: A Theory of Trade Expectations," International Security Vol. 20, No. 4 (Spring 1996), pp. 5-41; Dale C. Copeland, The Origins of Major War (Ithaca, N.Y.: Cornell University Press, 2000); Paul A. Papayoanou, "Interdependence, Institutions, and the Balance of Power: Britain, Germany, and World War I," International Security, Vol. 20, No. 4 (Spring 1996), pp. 42-76; Paul A. Papayoanou, Power Ties: Economic Interdependence, Balancing, and War (Ann Arbor: University of Michigan Press, 1999); Norrin M. Ripsman and Jean-Marc F. Blanchard, "Commercial Liberalism Under Fire: Evidence from 1914 and 1936," Security Studies, Vol. 6, No. 2 (Winter 1996/97), pp. 450; David M. Rowe, "World Economic Expansion and National Security in Pre-World War I Europe," International Organization, Vol. 53, No. 2 (Spring 1999), pp. 195-231; Jack S. Levy, “War and Peace," in Walter Carlsnaes, Thomas Risse, and Beth Simmons, eds., The Handbook of International Relations (London: Sage, 2001), pp. 350-367; David M. Rowe, "The Tragedy of Liberalism: How Globalization Caused the First World War," Security Studies, Vol. 14, No. 3 (Spring 2005), pp. 407-447; John J. Mearsheimer, The Tragedy of Great Power Politics (New York: W.W. Norton, 2001); Robert Jervis, "Theories of War in an Era of Leading Power Peace," American Political Science Review, Vol. 96, No. 1 (March 2002), pp. 1-14; and Frank Zagare, The Games of July: Explaining the Great War (Ann Arbor: University of Michigan Press, 2011), p. x.

2. Norman Angell, The Great Illusion, 2d ed. (New York: G.P. Putnam's Sons, 1933); Richard Rosecrance, The Rise of the Trading State: Commerce and Conquest in the Modern World (New York: Basic Books, 1985); and Patrick J. McDonald and Kevin Sweeney, "The Achilles' Heel of Liberal IR Theory? Globalization and Conflict in the Pre-World War I Era," World Politics, Vol. 59, No. 3 (April 2007), pp. 370-403. 
contributes to expectations about the future of international affairs. If interdependence at the turn of the last century failed to inhibit the most general conflict up to that time, then it may fail to perpetuate peace in the new century. Second, World War I serves as a "critical case" for proponents and critics of liberal theory. The liberal argument will be strengthened to the degree that economic integration a century ago can be reconciled with the outbreak of general war in Europe in 1914. Finally, World War I is an inherently important case, implying (as others have already suggested) that explanations for its advent and expansion deserve careful scrutiny.

Recasting the outbreak of World War I in a light more favorable to liberal theory is actually less difficult than the prevailing consensus would suggest. At the very least, World War I is not a particularly compelling example of the failure of liberal trade theory, and it may even indicate the strength of the liberal perspective. The conventional wisdom about interdependence and World War I seems peculiar in light of three historical facts. First, the turn of the century saw a series of intense crises among the interdependent states of Western Europe that nevertheless did not result in open warfare. Second, despite these growing tensions among the Western powers, the fighting in 1914 actually began among the less interdependent powers of Austria-Hungary and Serbia. Third, during the same period in which the highly interdependent European powers were generally able to resolve their crises without resorting to war, the less interdependent powers were typically unable to do so. These observations indicate that there may indeed have been a relationship between interdependence and the pacific settlement of disputes during this era. These facts also suggest that the role of interdependence in the outbreak of war in 1914 may be better understood in the context of the relationship between interdependence and conflict in the era leading up to the war.

We argue that the relationship between economic interdependence and the outbreak of World War I has been broadly misinterpreted and that interdependence did not really fail in 1914. World War I did happen, of course, but it is no coincidence that it began among states that were less well integrated into the global economy than their key alliance partners. There is much evidence to suggest that economic linkages served an important role in averting escalation to warfare in the series of crises that led up to the Great War. These crises, however, created an incentive for more integrated countries, most importantly, Germany and Russia, to show an increasing resolve to support their weaker, less interdependent, allies, Austria-Hungary and Serbia. Tight alliance ties then effectively handed the foreign policies of interdependent powers over to countries that were less well integrated into the world economy. Economic integration was incapable of forestalling conflict where integration had yet to oc- 
cur. Nor could interdependence prevent war, once started, from spreading through competing networks of military alliance commitments that made it much more costly for Western powers to take advantage of available economic linkages to the greatest pacific effect.

This article begins by explaining the various theories that argue that interdependence reduces the likelihood of conflict, as well as theories opposed to this view. Second, we discuss the shortcomings of treating the outbreak of World War I as a failure of interdependence. Third, we describe interdependence in the two economic subsystems of Europe prior to the war. In the fourth section, we compare crisis behavior in the highly interdependent and less interdependent portions of Europe during the period 1871 to 1913. Fifth, we discuss the July crisis and the outbreak of war in 1914. We conclude by using the evidence from our analysis to further refine commercial liberal theory.

\section{War and Interdependence}

Theories of interdependence argue that economic relationships that span international borders decrease the likelihood of states to engage in conflict. Nations inclined to war can be deterred, informed, or transformed by the value of economic linkages. Critics of interdependence argue that economic ties do not have powerful pacifying effects on world politics, either because the stakes are insufficient to deter conflict or because some aspect of the causal logic offered by liberals and others is incorrect.

The most traditional approach to the relationship between economic relations and conflict focuses on explaining how economic ties linking nations change the incentives of actors in the international system. Beginning in the modern era, scholar-statesmen such as Richard Cobden and Norman Angell argued that interdependence, primarily in the form of interstate trade, raises the opportunity costs of war, thus making contests less likely. The logic of these arguments is that a war between trading partners would likely disrupt that trade, forcing states to seek other markets. This would require a shift to different, less lucrative, trade partners. ${ }^{3}$ Others argue that, as trade increases, states can achieve gains more efficiently through economic means than through warfare. In other words, when states can grow their economies through international commerce, there is a decreased incentive to attempt to

3. Richard Cobden, Political Writings of Richard Cobden, Vol. 1 (London: T. Fisher Unwin, 1903 [1867]); Angell, The Great Illusion; Francis Delaisi, Political Myths and Economic Realities (London: Noel Douglas, 1925), pp. 57-78; and Richard N. Rosecrance and Arthur Stein, "Interdependence: Myth or Reality?" World Politics, Vol. 26, No. 1 (October 1973), pp. 1-27. 
do so through territorial conflict. ${ }^{4}$ Open financial and goods markets may also create similar disincentives for states to fight. ${ }^{5}$

The notion that international trade is associated with a decreased likelihood of conflict has found significant empirical support. A series of studies using events data found that higher levels of trade interdependence (defined as trade/gross domestic product [GDP]) are associated with lower probabilities of interstate war. ${ }^{6}$ Other studies have built on this research to demonstrate that the finding is robust to alternate specifications of the temporal domain and unit of analysis. ${ }^{7}$ The relationship between trade and conflict is likely more complex than initially theorized. First, high levels of trade dependence may embolden a state's opponents. ${ }^{8}$ Responding to this critique, Patrick McDonald argues that scholars must shift their focus from aggregate trade flows to the extent to which states pursue free trade policies. ${ }^{9}$ Han Dorussen offers another important theoretical refinement, noting that the opportunity costs of conflict created by different types of trade vary significantly. Two factors he points to that raise the opportunity costs of conflict created by trade are lower factor mobility and higher asset specificity. ${ }^{10}$ Finally, the effects of trade interdependence may be contingent on the mediating effects of democracy. ${ }^{11}$

One strain of research focuses on ways that trade may make conflict less likely through mechanisms other than raising the opportunity costs of war. Etel Solingen, for example, argues that trade allows domestic actors to build

4. Rosecrance, The Rise of the Trading State.

5. Arthur A. Stein, "Governments, Economic Interdependence, and International Cooperation," in Philip E. Tetlock, Jo L. Husbands, Robert Jervis, Paul C. Stern, and Charles Tilly, eds., Behavior, Society, and Nuclear War, Vol. 3 (New York: Oxford University Press, 1993); and Michael W. Doyle, Ways of War and Peace: Realism, Liberalism, and Socialism (New York: W.W. Norton, 1997).

6. Solomon W. Polachek, "Conflict and Trade," Journal of Conflict Resolution, Vol. 24, No. 1 (March 1980), pp. 55-78; Mark J. Gasiorowski, "Economic Interdependence and International Conflict: Some Cross-National Evidence," International Studies Ouarterlu, Vol. 30, No. 1 (March 1986), pp. 2338; and John R. Oneal and Bruce M. Russett, "The Classical Liberals Were Right: Democracy, Interdependence, and Conflict, 1950-1985," International Studies Quarterly Vol. 41, No. 2 (June 1997), pp. 267-293.

7. On specification of the temporal domain, see William K. Domke, War and the Changing Global System (New Haven, Conn.: Yale University Press, 1988). On the unit of analysis, see Edward D. Mansfield, Power, Trade, and War (Princeton, N.J.: Princeton University Press, 1994).

8. James D. Morrow, "How Could Trade Affect Conflict?" Iournal of Peace Research, Vol. 36, No. 4 (July 1999), pp. 481-489; and Erik Gartzke, Quan Li, and Charles Boehmer, "Investing in the Peace: Economic Interdependence and International Conflict," International Organization, Vol. 5, No. 2 (Spring 2001), pp. 391-438.

9. Patrick J. McDonald, "Peace through Trade or Free Trade?" Iournal of Conflict Resolution, Vol. 48, No. 4 (August 2004), pp. 547-572.

10. Han Dorussen, "Heterogeneous Trade Interests and Conflict: What You Trade Matters," Iournal of Conflict Resolution, Vol. 50, No. 1 (February 2006), pp. 87-107, at p. 90.

11. Papayoanou, Power Ties; and Christopher Gelpi and Joe Grieco, "Economic Interdependence, the Democratic State, and the Liberal Peace," in Edward D. Mansfield and Brian M. Pollins, eds., Economic Interdependence and International Conflict (Ann Arbor: University of Michigan Press, 2003). 
cross-national coalitions that both promote greater interdependence and cause convergent transformations in state preferences. ${ }^{12}$ Along related lines, Paul Papayoanou argues that economic relations create strong domestic-level interests that delimit a leader's ability to credibly counter external threats or challenges. ${ }^{13}$ Building on these arguments, several scholars have constructed what is sometimes known as the "commercial peace" or "capitalist peace" view of the relationship between economics and war. They argue that interdependence mollifies the effects of states' security dilemmas by creating common interests and reducing uncertainty. Although the bulk of the work on interdependence and conflict focuses on trade, ${ }^{14}$ other forms of transnational economic relations are also crucial. Erik Gartzke, Quan Li, and Charles Boehmer argue that, along with trade, interstate monetary policy cooperation and capital flows reduce the likelihood of conflict by allowing states in crisis situations to send costly signals without needing to resort to violence or crisis escalation that may precipitate violence. ${ }^{15}$ Building on this, Gartzke argues that interdependence-defined as including trade, development, open financial markets, and monetary policy coordination-reduces conflict by (1) aligning states' interests, which gives them less to fight over; (2) providing a means of peacefully securing resources; and (3) allowing states to foresee the costs of fighting, which facilitates bargaining and compromise. ${ }^{16}$

A significant group of scholars, however, have posed important criticisms of interdependence theory. At a theoretical level, several scholars have claimed that interdependence and conflict are unrelated. Even if economic factors matter, they argue, decisions to initiate conflict are primarily based on security and military concerns. ${ }^{17}$ James Morrow provides two arguments against the causal

12. Etel Solingen, Regional Orders at Century's Dawn: Global and Domestic Influences on Grand Strategy (Princeton, N.J.: Princeton University Press, 1998).

13. Papayoanou, Power Ties.

14. In addition to the work cited above, see John R. Oneal and James Lee Ray, "New Tests of the Democratic Peace: Controlling for Economic Interdependence, 1950-85," Political Research Quarterly, Vol. 50, No. 4 (December 1997), pp. 751-775; Mark J.C. Crescenzi and Andrew J. Enterline, "Time Remembered: A Dynamic Model of Interstate Interaction," International Studies Ouarterly, Vol. 45, No. 3 (September 2001), pp. 409-431; and John R. Oneal, Bruce Russett, and Michael L. Berbaum, "Causes of Peace: Democracy, Interdependence, and International Organizations," International Studies Ouarterlu, Vol. 47, No. 3 (September 2003), pp. 371-393.

15. Gartzke, Li, and Boehmer, "Investing in the Peace."

16. Erik Gartzke, "The Capitalist Peace," American Iournal of Political Science, Vol. 51, No. 1 (January 2007), pp. 166-191. See also William Reed, "Information and Economic Interdependence," Lournal of Conflict Resolution, Vol. 47, No. 1 (February 2003), pp. 54-71; and Patrick J. McDonald, The Invisible Hand of Peace: Capitalism, the War Machine, and International Relations Theory (Cambridge: Cambridge University Press, 2009).

17. Barry Buzan, "Economic Structure and International Security: The Limits of the Liberal Case," International Organization, Vol. 38, No. 4 (August 1984), pp. 597-624; and Jack S. Levy, "The Causes of War: A Review of Theories and Evidence," in Philip E. Tetlock, Jo L. Husbands, Robert Jervis, 
connection between trade and conflict. First, if trade reduces aggressive behavior by one state, this would strategically have the effect of increasing the likelihood of aggressiveness by another state, thus nullifying the effect of interdependence in inhibiting conflict. Second, Morrow argues that firms should rationally anticipate when conflict with other states is more likely and strategically reduce their trade with firms in those states. ${ }^{18}$ As a result, trade may be endogenous to conflict, or the direction of causality may be the reverse of that theorized by commercial liberals. ${ }^{19}$ Omar Keshk, Brian Pollins, and Rafael Reuveny investigate this problem, finding evidence that it is more likely that conflict affects trade than vice versa. ${ }^{20}$ Similarly, Michael Ward, Randolph Siverson, and Xun Cao argue that prior statistical findings are the result of geographical proximity, dependence among militarized disputes with the same initiator or target, and higher-order dependencies in dyadic data. Accounting for these, they find no relationship between trade levels and conflict. ${ }^{21}$

Others argue that trade increases, rather than decreases, the likelihood of conflict, a result that would support the Marxist view that capitalism leads to conflict. Generally speaking, capitalism and economic development may generate demands for imperialistic territorial conquest. As commerce grows, states compete over scarce resources and may use military means to obtain them. States may also use trade and military force together to maintain their colonial holdings. Economic ties may create rivalries as partners become more concerned with dividing the gains from the trade than with mutual gains. ${ }^{22}$ Several political scientists have built on these arguments, noting that trade may increase conflict by creating competition over relative gains. ${ }^{23}$ There is also some empirical support for this proposition, although it is controversial.

Paul C. Stern, and Charles Tilly, eds., Behavior, Society, and Nuclear War, Vol. 1 (New York: Oxford University Press, 1989).

18. Morrow, "How Could Trade Affect Conflict?"

19. Rafael Reuveny, "Bilateral Import, Export, and Conflict/Cooperation Simultaneity," International Studies Ouarterly, Vol. 45, No. 1 (March 2001), pp. 131-158.

20. Omar M. Keshk, Brian M. Pollins, and Rafael Reuveny, "Trade Still Follows the Flag: The Primacy of Politics in a Simultaneous Model of Interdependence and Armed Conflict," Journal of Politics, Vol. 66, No. 4 (November 2004), pp. 1155-1179.

21. Michael D. Ward, Randolph M. Siverson, and Xun Cao, "Disputes, Democracies, and Dependencies: A Reexamination of the Kantian Peace," American Journal of Political Science, Vol. 51, No. 3 (July 2007), pp. 583-601.

22. John A. Hobson, Imperialism (Ann Arbor: University of Michigan Press, 1938 [1905]); V.I. Lenin, Imperialism: The Highest Stage of Capitalism (New York: International Publishers, 1970 [1916]); Albert O. Hirschman, National Power and the Structure of Foreign Trade (Berkeley: University of California Press, 1945); and Benjamin J. Cohen, The Question of Imperialism (New York: Basic Books, 1973).

23. Michael Mastanduno, “Do Relative Gains Matter? America's Response to Japanese Industrial Policy," International Securitu, Vol. 16, No. 1 (Summer 1991), pp. 73-113; and Joanne Gowa, Allies, Adversaries, and International Trade (Princeton, N.J.: Princeton University Press, 1994). 
Using a measure of trade salience, Katherine Barbieri finds statistical support for this proposition for the period 1870 to $1938 .^{24}$

\section{World War I as a Test of Liberal Theory}

The causes of World War I have long been an important topic of debate and conjecture among students of international politics. ${ }^{25}$ The case appears particularly problematic for those claiming that interdependence reduces the likelihood of war. In the four decades prior to the Great War, Europe experienced a dramatic increase in the levels of interdependence, especially among several of the major powers. Liberal theory, therefore, would appear to predict a low probability of war among interdependent European states and a low probability that wars would spread to countries with globalized economies. That interdependent states engaged in a war of unprecedented intensity thus bolsters the view that interdependence is not an important determinant of conflict. ${ }^{26}$

Several scholars have attempted to defend or explain away the onset of war in 1914 in light of the apparent contradiction with liberal theory. John Oneal and Bruce Russett argue that the effects of interdependence are conditional on democracy. Thus, these effects did not function in the lead-up to the war because Germany was not sufficiently democratic. They also argue that, although economic interdependence was much greater during this period than in prior eras, it was nonetheless not sufficiently deep as to prevent a major conflict, a point that Richard Rosecrance also makes. Rosecrance, repeating an argument posed by Angell, also claims that European leaders misperceived both the value of interdependence and the costs of a potential war. ${ }^{27}$ Patrick

24. Katherine Barbieri, "Economic Interdependence: A Path to Peace or a Source of International Conflict?" Lournal of Peace Research, Vol. 33, No. 1 (February 1996), pp. 29-49. For critiques, see John R. Oneal and Bruce Russett, "Assessing the Liberal Peace with Alternative Specifications: Trade Still Reduces Conflict," Iournal of Peace Research, Vol. 36, No. 4 (July 1999), pp. 423-442; and Erik Gartzke and Quan Li, "Measure for Measure: Concept Operationalization and the Trade Interdependence-Conflict Debate," Iournal of Peace Research, Vol. 40, No. 5 (September 2003), pp. 553-571. 25. Jack Snyder, "Civil-Military Relations and the Cult of the Offensive, 1914 and 1984," International Security, Vol. 9, No. 1 (Summer 1984), pp. 108-146; Scott D. Sagan, "1914 Revisited: Allies, Offense, and Instability," International Security, Vol. 11, No. 2 (Autumn 1986), pp. 151-175; Marc Trachtenberg, "The Meaning of Mobilization in 1914," International Securitu, Vol. 15, No. 3 (Winter 1990/91), pp. 120-150; Jack S. Levy, "Preferences, Constraints, and Choices in July 1914," International Securitu, Vol. 15, No. 3 (Winter 1990/91), pp. 151-186; and Keir Lieber, "The New History of World War I and What It Means for International Relations Theory," International Security, Vol. 32, No. 2 (Fall 2007), pp. 155-191.

26. E.H. Carr, The Twenty Years' Crisis: 1919-1939 (London: Macmillan, 1939); Waltz, Theory of International Politics; John J. Mearsheimer, "Back to the Future: Instability in Europe after the Cold War," International Security, Vo. 15, No. 1 (Summer 1990), pp. 5-56; and Copeland, "Economic Interdependence and War."

27. John R. Oneal and Bruce Russett, Triangulating Peace: Democracy, Interdependence, and Interna- 
McDonald and Kevin Sweeney provide a detailed analysis delineating the relationship between interdependence and the outbreak of World War I. They argue that most theories of commercial liberalism incorrectly focus on trade flows rather than on trade protection. They find that during the period 1865 to 1914 , lower levels of trade protection were associated with a reduced propensity toward conflict, showing that interdependence (following their definition) was associated with peace during this era. In addition, they note that economic conflict between Germany and Russia, in the form of rising tariff rates, preceded the outbreak of war.

We build on McDonald and Sweeney's argument by asking to what extent the outbreak of World War I can be viewed as a failure of interdependence. We differ in how we define interdependence, adopting the more conventional association between trade flows and conflict, rather than examining protectionist measures, which strike us as closely associated with the very forces propelling states to war. We also differ from McDonald and Sweeney in our focus on the competing interconnectedness of alliance ties and their role in overcoming the pacifying effect of national economic interest that deterred conflict among interdependent states prior to World War I.

On the surface, it would seem clear that interdependence failed to function as predicted by liberal theory at the advent of World War I. Yet there are three key flaws in the connections drawn by both critics and advocates of liberal theory that make such a conclusion empirically suspect. First, the occurrence of war between interdependent states in one important case demonstrates only that interdependence is not sufficient by itself to guarantee interstate peace; interdependence could still reduce the overall likelihood of war. Second, focusing on the outbreak of World War I to test this theory is problematic because it is a case chosen based on the dependent variable, the outbreak of war. War may be made very unlikely and nonetheless occur. If we are to look back afterward and conclude that the likelihood of war was not much affected by mitigating factors, then we are committing the classic post hoc, ergo propter hoc fallacy. We can gain greater explanatory power by examining the variance in this dependent variable over the relevant period. Third, the conventional wisdom-that Europe was interdependent but nonetheless went to waroverlooks crucial variance in the independent variable. Europe in 1914 was not uniformly interdependent, but consisted of several highly interdependent powers, other powers that were significantly less reliant on economic relations with their neighbors, and still other states that were minimally integrated into this system. We discuss all three issues below. 
First, while a probabilistic theory cannot be disproved with a single case, a reasonable observer might counter that some cases are particularly worth explaining. Liberal theory is deeply flawed if it cannot account for a contest as catastrophic as World War I. We agree completely. Treating a war in which more than 10 million people died as an outlying case in which a probabilistic relationship failed would be intellectually unsatisfactory and misleading. World War I was not just a blip.

The second flaw with using 1914 to test theories of interdependence, however, is more consequential. While many scholars have argued that it is not appropriate to choose cases based on the dependent variable, ${ }^{28}$ others argue that doing so is valid when one is particularly interested in explaining a specific case or outcome. ${ }^{29}$ We take no issue with the study of World War I as a unique historical phenomenon or with including interdependence as a possible explanatory variable when attempting to explain what did or did not contribute to its outbreak. Instead, our concern is that scholars have made erroneous inferences in using the Great War to falsify liberal theory more generally. Doing so uses the July 1914 crisis as a "hypothesis testing" case, which is among the most difficult and controversial types of case study. ${ }^{30}$ It is one thing to study a case to understand what led to a particular outcome in that case; it is a wholly different undertaking to use the case to test a hypothesis meant to represent general tendencies of a variable across a great many cases. While Gary King, Robert Keohane, and Sidney Verba doubt that valid inference can be drawn from testing a hypothesis with a single case, others argue that doing so is valid for crucial or critical cases, often referred to as "most likely" and "least likely" cases. $^{31}$

Conducting a hypothesis-testing case study of a probabilistic theory based on a most/least likely logic requires analysts to define their case based on the independent variable rather than the dependent variable. What makes the outbreak of World War I relevant to theories of interdependence is not just that it was a war, but that it was a war that involved several powers that were formerly highly interdependent. Thus, to use this case to test the hypothesis that

28. Gary King, Robert O. Keohane, and Sidney Verba, Designing Social Inquiry: Scientific Inference in Qualitative Research (Princeton, N.J.: Princeton University Press, 1994).

29. Henry E. Brady and David Collier, Rethinking Social Inquiry: Diverse Tools, Shared Standards (Lanham, Md.: Rowman and Littlefield, 2004).

30. Harry Eckstein, "Case Studies and Theory in Political Science," in Fred I. Greenstein and Nelson W. Polsby, eds., Handbook of Political Science, Vol. 7 (Reading, Mass.: Addison-Wesley, 1975); and Jack S. Levy, "Case Studies: Types, Designs, and Logics of Inference," Conflict Management and Peace Science, Vol. 25, No. 1 (March 2008), pp. 1-18.

31. Eckstein, "Case Studies and Theory in Political Science." As Jack Levy argues, "The inferential logic of least likely case design is based on the 'Sinatra inference'-if I can make it there, I can make it anywhere. The logic of most likely case design is based on the inverse Sinatra inference-if I cannot make it there, I cannot make it anywhere." Levy, "Case Studies," p. 12. 
interdependence reduces the probability of conflict, we must define it in terms of an era of high European interdependence and study conflict behavior in the period and region as a whole. As David Stevenson argues, "[T]o concentrate exclusively on the events of 1914 provides too narrow a basis for understanding early-twentieth-century crisis behavior. We need to study the confrontations that did not end in fighting as well as the ones that did." 32 Put another way, when defining a case analysts must ask themselves: "What is this a case of?" 33 We argue that an answer of "This is a case of war" may allow us to understand the causes of that war, or possibly the causes of war in general. Yet only by defining the case as "a case of high interdependence and war" can we understand whether this factor makes war less likely. To do otherwise, to test this hypothesis by defining the case as the outbreak of war in July 1914, is to commit a fallacy as significant in turn as it would be to dismiss the war as an "outlier."

Defining the case in this way brings us to the third flaw in the conventional wisdom: the role of the explanatory variable. The notion that World War I represents a crucial failure of interdependence seems to rely on the view that it a most likely case for testing the hypothesis. World War I, as we noted above, is often cited as evidence against commercial liberalism. On its face, the case involves a period of significant and increasing interdependence followed by a war, and thus presents a problem for those who argue that interdependence promotes peace. If instead even this case offers some support for liberal claims, then this is powerful evidence in favor of the liberal perspective. Yet treating 1914 alone as a most likely case in the traditional sense overlooks several historical facts that are inconsistent with framing the case in this way. First, not all of Europe was economically interdependent during the pre-World War I period; indeed, this factor varied in crucial ways across both space and time. Ian Beckett explains this difference as follows: "The rapid pace of change wrought by industrialization in western Europe sharpened the contrast with most of the states of central, southern and eastern Europe. These remained in effect peasant societies." ${ }^{34}$ Second, the war did not begin among the most interdependent states in Europe but instead among their less interdependent allies. A more clear-cut most likely case to test liberal theory would have been a war that began between Germany and Russia or France. Certainly, Austria-Hungary and Serbia were supported and possibly encouraged by their allies, but the fact re-

32. David Stevenson, "Militarization and Diplomacy in Europe before 1914," International Security Vol. 22, No. 1 (Summer 1997), pp. 125-161, at p. 154.

33. Levy, "Case Studies."

34. Ian F.W. Beckett, The Great War, 2d ed. (London: Pearson, 2007), p. 5. 
mains that, despite rising tensions in the West, the war began on the banks of the Danube, not the Rhine. Interdependence may have played a more important and nuanced role than is widely recognized, as exhibited by the pattern of initiation, joining, and nonjoining by European states.

Our research design is intended to provide a more comprehensive test of the question of whether the outbreak of World War I constitutes a failure of interdependence. To answer this question in a manner that overcomes the shortcomings outlined above, we address two sub-questions. First, is there historical evidence that interdependence made the war less likely than it would have been otherwise? Second, if so, why did war break out in 1914 despite these effects? We begin by analyzing crisis behavior in Europe in the era prior to World War I. This allows us to observe multiple cases of crises that vary both along the dependent variable of crisis outcome (e.g., escalation or de-escalation) and the key independent variable of interdependence. Although it is possible to define any previous point in history as beginning the lead-up to the war, many historians begin their study of the war's origins in 1871, following Germany's victory in the Franco-Prussian War. Crises among the highly interdependent powers-most importantly, Britain, France, Germany and Russia-were generally resolved peacefully during this era, despite important differences among these powers. By contrast, crises among the less interdependent powers of Europe in this period often led to war.

We continue our analysis by examining the July 1914 crisis. We do so for two reasons. First, as mentioned above, regardless of the methodological arguments one might make to the contrary, it is important to understand why interdependence failed to prevent a wider war in 1914. Second, deviant case analyses can be useful for the refinement and extension of hypotheses. ${ }^{35}$ By examining July 1914 within the broader context, we hope to provoke a refinement or extension of liberal theory.

While our research design has several advantages, it also has limitations. These limitations are not unique to our study, but are characteristic of any attempt to draw inferences in small samples. We cannot conclusively demonstrate that interdependence "worked" in 1914, but rather that the widely accepted view that interdependence failed to promote peace is poorly supported. ${ }^{36}$ In an ideal world, we could go further and "process trace" our

35. Imre Lakatos, "Falsification and the Methodology of Scientific Research Programmes," in Lakatos and Alan Musgrave, eds., Criticism and the Growth of Knowledge (New York: Cambridge University Press, 1970), pp. 91-196; and Levy, "Case Studies."

36. Liberal theory does not argue that noninterdependence is a cause of war (i.e., increasing the likelihood of conflict), but rather that interdependence is a cause of peace, reducing motivations to fight below what they might be otherwise. 
argument, providing detailed narratives showing that de-escalation among interdependent states in crisis resulted (at least in part) from concern among key decisionmakers over jeopardizing economic relations. Beyond the fact that we lack space to conduct such analyses here, evidence of this type may not be forthcoming. A lack of discussions about trade, for example, could be interpreted as proof that leaders were unaffected by economic considerations. The leaders most affected by economic ties, however, may refrain from entering crises altogether, making assessments of their (non)actions far from transparent. Few would find it surprising if leaders of less interdependent states that escalated to war failed to include in their reasons for fighting their lack of economic interdependence, but leaders who fail to fight for economic reasons may end up attributing their timidity to discretion or diplomacy. Leaders may also adopt measures that mitigate the effects of interdependence, such as tight alliance ties. In short, the absence of evidence cannot be interpreted as evidence of absence. The conventional narrative on economic interdependence and World War I relies on observable behavior (i.e., there was a war, thus economic factors failed to deter war) to judge the inefficacy of economic interdependence, so we also focus on such behavior to support our argument, at least initially.

One thing we can demonstrate is that a correlation exists between interdependence levels and conflict in Europe during this era. ${ }^{37}$ The correlation is important for two reasons. First, it casts prima facie doubt on the view of 1914 as an adequate "most likely" test of commercial liberalism. If it is truly a most likely case with which to test the theory, appropriately defined in terms of the independent variable, then a finding that crises among interdependent states during this era tended to result in conflict would provide strong evidence against liberal theory. If they did not, however, then this would suggest that the use of World War I to falsify commercial liberalism is myopic and that the role of interdependence in the origins of the war deserves greater attention. Second, the correlation is useful for counterfactual analysis. By identifying the most salient sources of tension during the era, we can predict ex ante where war would have been most expected if interdependence and war are unrelated. By then comparing crisis behavior in response to such tensions among highly and weakly interdependent groups of states, we can use the groups as counterfactuals for each other.

37. Patrick McDonald and Kevin Sweeney have already demonstrated that states with higher levels of trade protection were more likely to engage in conflict in 1914. McDonald and Sweeney, "The Achilles' Heel of Liberal IR Theory?" 


\section{Interdependence in Pre-World War I Europe}

We define "economic interdependence" broadly, as consisting of both trade and capital flows. Groups of interdependent states are those connected by dense trade and capital flows, whereas less interdependent states and groups are closer to autarky. Although data are not available for every state we address in each year, we possess enough information to develop key conclusions regarding categories of states, their relative levels of interdependence, and the effects of economic linkages on conflict in this period.

It is possible to think of Europe during this era as consisting of two distinct economic subsystems. The first is a highly interdependent group consisting mostly of Western powers, most importantly, Germany, France, and the United Kingdom, but also Russia. The second subsystem is a significantly less interdependent group of Eastern European states, including the Ottoman Empire, its successor states, and again Russia. Scholars generally agree that, between 1871 and the beginning of World War I, many European powers became increasingly economically interdependent, particularly in terms of increased trade and capital mobility. The highly interdependent states in Europe were mostly in the West, including Belgium, Britain, Denmark, France, Germany, Holland, Norway, and Sweden. Other powers, such as Austria-Hungary, Italy, and Russia were significantly less developed economically and less integrated into the global economy, although Russia was heavily dependent in economic terms on the Western powers. The least economically integrated and developed of the European powers at the time were the Ottoman Empire and its various successor states, as well as the Iberian states. The key Western powers of Britain, France, and Germany constituted a highly economically interdependent group to which Russia was also attached. Austria-Hungary was connected to this group, largely via its economic relations with Germany, but its economic ties to other Western nations were far less significant. By contrast, no such economically interdependent group existed in the East. The key Eastern powers-Austria-Hungary, the Ottoman Empire and its successor states, and Russia-conducted relatively little of their economic relations with one another. ${ }^{38}$

38. Albert Fishlow, "Lessons from the Past: Capital Markets during the 19th Century and the Interwar Period," International Organization, Vol. 39, No. 3 (Summer 1985), pp. 383-439; Peter J. Katzenstein, "International Interdependence: Some Long-Term Trends and Recent Changes," International Organization, Vol. 29, No. 4 (Autumn 1975), pp. 1021-1034; Ripsman and Blanchard, "Commercial Liberalism Under Fire"; Jeffrey G. Williamson, "Globalization and the Great Divergence: Terms of Trade Booms, Volatility, and the Poor Periphery, 1782-1913," European Review of 
Figure 1. Trade Levels in Western Europe, 1870-1913

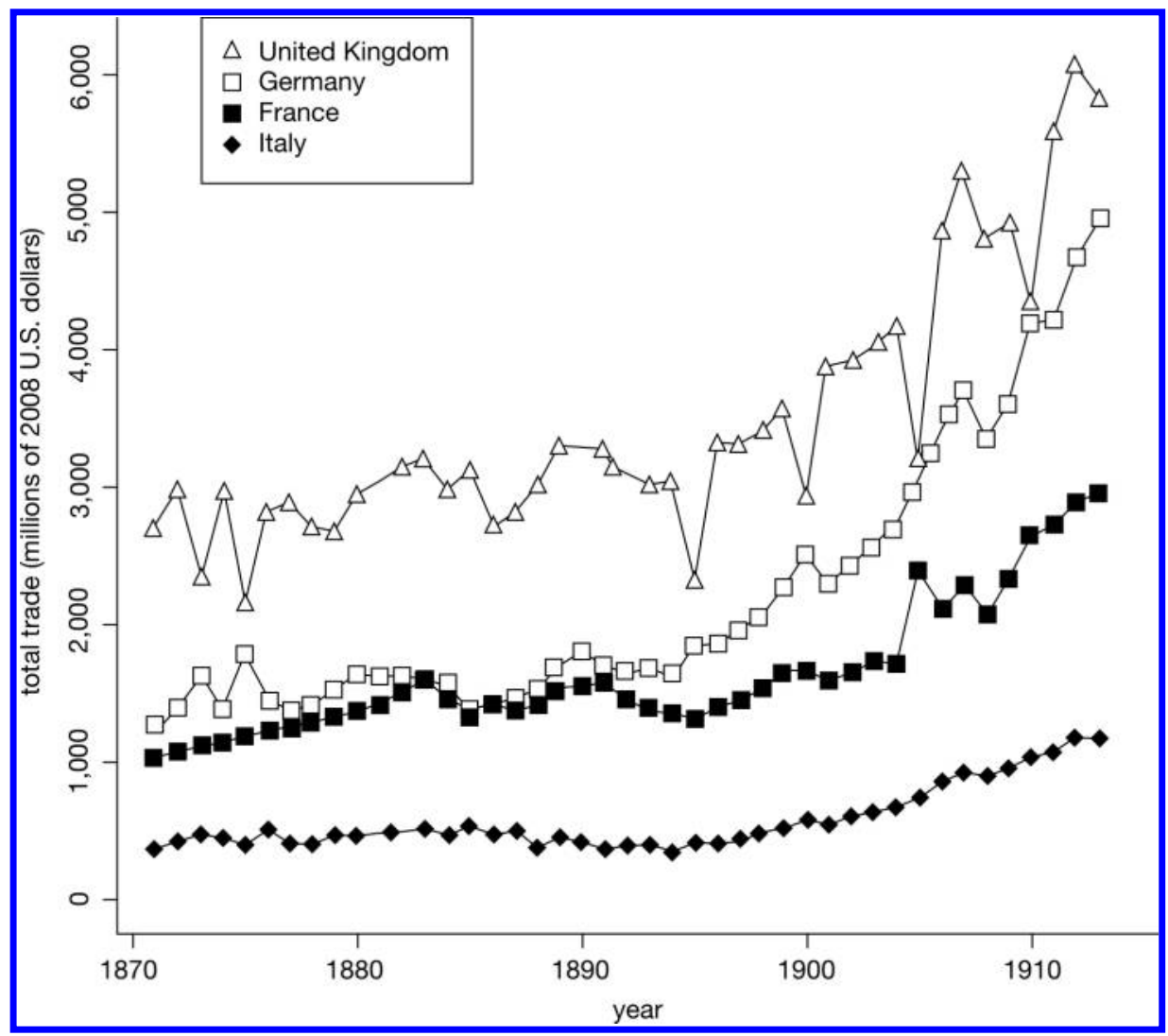

We use the trade levels of the key powers during this era to illustrate the two European subsystems. Several dimensions of monadic economic development and dyadic economic relations are argued to reduce the risk of conflict, perhaps the most analyzed of which is trade. As figures 1 and 2 illustrate using data from the Correlates of War (COW) project, ${ }^{39}$ Britain, France, and Germany were the key trade powers in Europe. In a second tier were Austria-Hungary, Italy, and Russia, all with trade levels of more than \$1 billion (2008 U.S. dol-

Economic History, Vol. 12, No. 3 (December 2008), pp. 355-391; and Christopher Blattman, Jason Hwang, and Jeffrey G. Williamson, "Winners and Losers in the Commodity Lottery: The Impact of Terms of Trade Growth and Volatility in the Periphery 1870-1939," Lournal of Development EconomicS, Vol. 82, No. 1 (January 2007), pp. 156-179.

39. Katherine Barbieri, Omar Keshk, and Brian Pollins, Correlates of War Project Trade Data Set Codebook, ver. 2, 2008. 
Figure 2. Trade Levels in Eastern Europe, 1870-1913

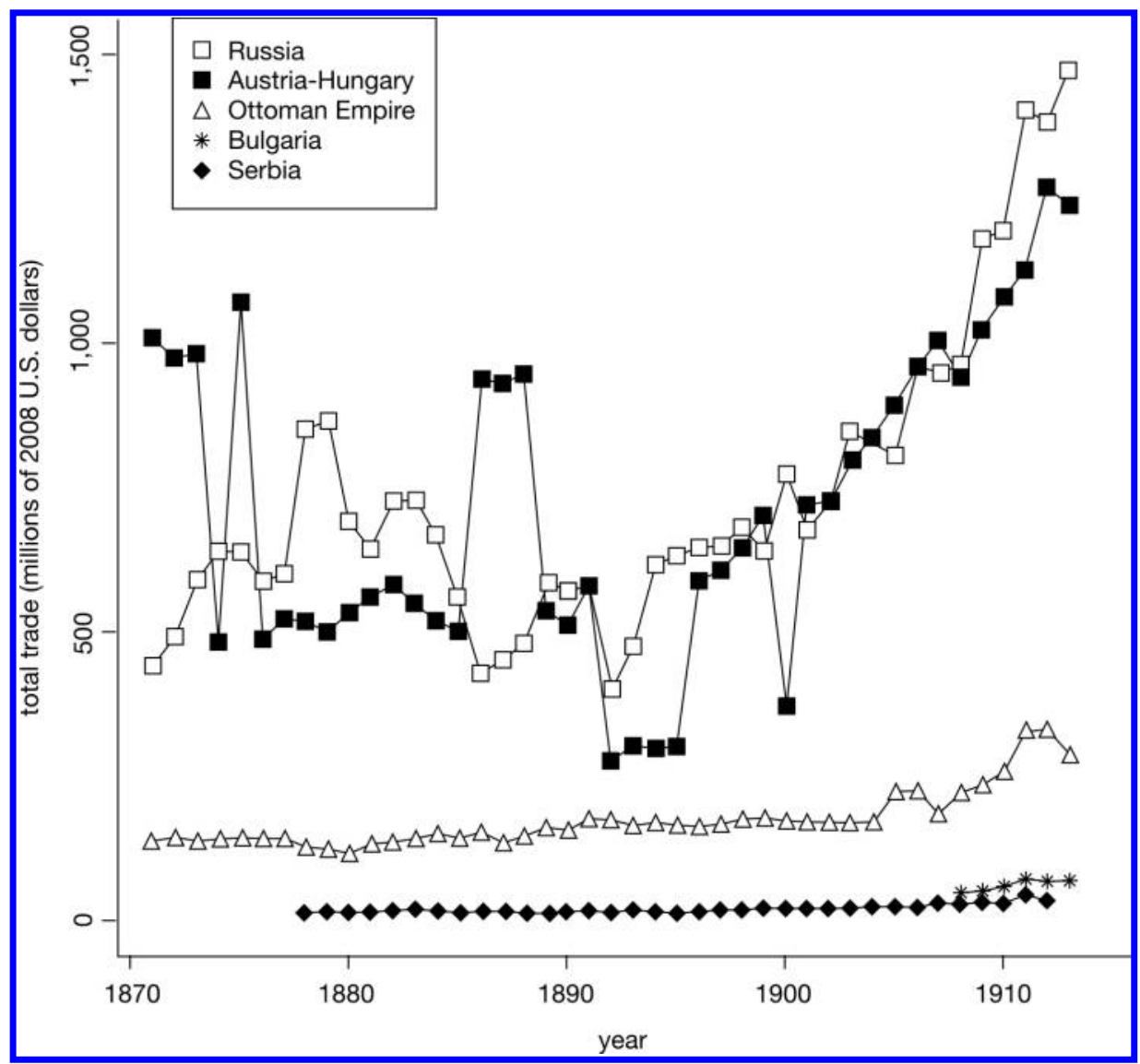

lars) by the outbreak of the war. The Ottoman Empire and the Balkan states, however, traded relatively little.

Similar trends can be observed in the levels of dyadic trade dependence during this era. Scholars have debated whether dependence should be measured as dyadic trade relative to income or dyadic trade relative to total trade. ${ }^{40} \mathrm{We}$ need not weigh in on this debate, however, as GDP data are generally unavailable for the period. ${ }^{41}$ We define "trade dependence" for country $i$ on country $j$ as:

40. Gartzke and Li, "Measure for Measure"; and Katherine Barbieri and Richard Alan Peters II, "Measure for Mismeasure: A Response to Gartzke \& Li," Iournal of Peace Research, Vol. 40, No. 6 (November 2003), pp. 713-719.

41. Peter Katzenstein reports the following ratios of monadic trade to GDP for the pre-World 


$$
\text { Dependence }_{i j t}=\frac{x_{i j_{t}}+m_{i j_{t}}}{\text { TotalTrade }_{i_{t}}} \text {. }
$$

Table 1 provides the dyadic levels of trade dependence among the key states in 1913. It should be noted that there are missing observations in the COW data for this period, so we are not able to calculate trade dependence for all of the relevant dyads. ${ }^{42} \mathrm{~A}$ few patterns are evident. First, the largest dyadic trade relationships by sheer volume generally involve trade within Western Europe, between the West and Russia, and between Germany and Austria-Hungary. The dyadic data show that these powers were also highly trade interdependent. By 1913, for example, Russia depended on Germany for 45 percent of its trade, while Germany conducted 13 percent of its trade with Russia. ${ }^{43}$ The extent of economic interdependence between Germany and Russia was a key factor in shaping their crisis bargaining incentives, as we explain below. Among the four Western powers and Russia, the average trade flow in 1913 was \$290 million (2008 U.S. dollars), while the average dyadic trade dependence was 10.3 percent. Put another way, this group of states was highly interdependent. By contrast, the volume of trade flows between the Eastern powers remained minor throughout this era, reaching an average in 1913 of \$17 million (2008 U.S. dollars). Most Eastern dyads were much less trade dependent on each other, the few exceptions being countries that traded heavily with Austria-Hungary. The average dyadic trade dependence among the Eastern powers was only 5 percent in 1913, most of which resulted from Ottoman and Bulgarian dependence on Austria-Hungary. Although we cannot calculate the trade dependence between Austria-Hungary and Serbia using these data,

War I period: France, 53.7 percent; Germany, 38.3 percent; Italy, 28.1 percent; and the United Kingdom, 43.5 percent. Katzenstein, "International Interdependence," p. 1032. Relying on newer data, Paul Papayoanou reports that "[f]or the three biggest European powers, total trade (exports and imports) as a percentage of gross national product (GNP) was 38 percent for Germany, 52 percent for Great Britain, and 54 percent for France in the years leading up to World War I, and much of their trade was with one another." Papayoanou, "Interdependence, Institutions, and the Balance of Power," p. 55. Finally, Michael Huberman and Wayne Lewchuk rank sixteen European countries (not including the Balkans) in terms of monadic trade over GDP in 1913. Only Portugal (13 percent) ranks lower than Austria-Hungary (16 percent). Huberman and Lewchuk, "European Economic Integration and the Labor Compact, 1850-1913," European Review of Economic History, Vol. 7, No. 1 (April 2003), pp. 3-41.

42. COW provides no data on Serbian trade in 1913. Monadic trade in 1912 is reported at only $\$ 37$ million (2008 U.S. dollars). Barbieri, Keshk, and Pollins, Correlates of War Project Trade Data Set Codebook.

43. According to Ian Beckett, "Between 1905 and 1914 Russo-German trade was immensely important, with Russia sending 44 percent of her exports to Germany and receiving 47 percent of her imports from Germany." Beckett, The Great War, p. 28. See also William Jannen Jr., The Lions of July: Prelude to War, 1914 (Novato, Calif.: Presidio, 1996), p. 83. 
Table 1. Dyadic Trade Dependence in 1913

\begin{tabular}{|c|c|c|c|c|}
\hline Country A & Country B & $\begin{array}{l}\text { Total Dyadic } \\
\text { Trade }\end{array}$ & $\begin{array}{l}\text { Dependence } \\
\text { A-B }\end{array}$ & $\begin{array}{l}\text { Dependence } \\
\text { B-A }\end{array}$ \\
\hline Bulgaria & Ottoman Empire & 1.98 & 2.78403 & 0.69814 \\
\hline Italy & Bulgaria & 1.98 & 0.16915 & 2.78403 \\
\hline France & Bulgaria & 3.37 & 0.11408 & 4.73847 \\
\hline United Kingdom & Bulgaria & 4.67 & 0.08 & 6.56637 \\
\hline Bulgaria & Russia & 6.05 & 8.50675 & 0.41027 \\
\hline Germany & Bulgaria & 10.15 & 0.20499 & 14.27165 \\
\hline Austria-Hungary & Bulgaria & 12.93 & 1.04397 & 18.18054 \\
\hline Russia & Ottoman Empire & 27.62 & 1.87299 & 9.73873 \\
\hline Italy & Ottoman Empire & 28.94 & 2.47238 & 10.20415 \\
\hline France & Austria-Hungary & 31.96 & 1.08194 & 2.58046 \\
\hline France & Ottoman Empire & 34.14 & 1.15574 & 12.03766 \\
\hline Austria-Hungary & Ottoman Empire & 37.14 & 2.99869 & 13.09545 \\
\hline Germany & Ottoman Empire & 40.89 & 0.82582 & 14.41769 \\
\hline Austria-Hungary & Russia & 51.45 & 4.15408 & 3.48896 \\
\hline Italy & Russia & 53.68 & 4.58596 & 3.64019 \\
\hline United Kingdom & Austria-Hungary & 57.92 & 0.99221 & 4.67647 \\
\hline United Kingdom & Ottoman Empire & 60.85 & 1.04241 & 21.45552 \\
\hline Austria-Hungary & Italy & 92.35 & 7.45636 & 7.88959 \\
\hline France & Italy & 100.28 & 3.39478 & 8.56706 \\
\hline France & Russia & 117.42 & 3.97502 & 7.96257 \\
\hline United Kingdom & Italy & 148.7 & 2.54734 & 12.70365 \\
\hline Germany & Italy & 191.83 & 3.87423 & 16.3883 \\
\hline United Kingdom & Russia & 276.28 & 4.73288 & 18.73529 \\
\hline France & Germany & 344.71 & 11.66946 & 6.96181 \\
\hline United Kingdom & France & 416.4 & 7.13324 & 14.09638 \\
\hline Germany & Austria-Hungary & 458.5 & 9.25993 & 37.01939 \\
\hline United Kingdom & Germany & 583.31 & 9.99253 & 11.78061 \\
\hline Germany & Russia & 670.34 & 13.53828 & 45.45757 \\
\hline
\end{tabular}

the consequences of the Pig War, discussed below, suggest that trade was low between them by this period.

\section{European Crises, 1871-1913}

Wars often appear inevitable in retrospect, but few wars seemed more unlikely to contemporaries in the preceding years than World War I. Journalists at the time, and historians in later periods, emphasize that Europe, or at least the West, had largely discounted the danger of a major conflagration by the summer of 1914. Why should this be so? Certainly, European history did not suggest that peace was inevitable, or even particularly durable. Warfare had been such a regular feature of European politics that it is hard to escape the conviction that war was overdue. One reason for optimism in the West about the durability of peace was that stability had been tested several times and found to 
be robust. A series of crises involving Germany, France, Britain, and Russia repeatedly seemed to take Europe to the brink of war, only to abate as the benefits of existing commercial relations asserted themselves. This reinforced the view that mutual interest, diplomacy, or civilization made it clear to affected leaders that war was not in their interest.

In part for these reasons, few conflicts have received more careful attention from historians and students of international affairs than World War I. So much has been said and written about the Great War that key aspects are substantially understood. The lasting interest in World War I clearly stems in part from its size. But this "war to end all wars" grew by increments, after the perennial, if much smaller, conflict in the Balkans had already established itself. Yet, it is still important to remember that the Great War did begin in the Balkans. If one wants to know why World War I became so large, then it is reasonable to explore joining by the major European powers. If instead one wants to know how and why World War I began, as a war, then it makes more sense to focus on Serbia and Austria-Hungary. The point is that war in the Balkans was no surprise to anyone and requires no special explanation. The same era in which disputes tended to be defused in the West, conflict on the edges of Europe flared up repeatedly. The rest of Europe had managed to keep these contests localized, however. The expansion of a Balkan war is what citizens in the West had discounted, and when the expansion came, it came as a surprise.

\section{THE HIGHLY INTERDEPENDENT SUBSYSTEM}

The late nineteenth and early twentieth centuries in Europe were marked by considerable tensions and a number of crises, including crises both between states that were highly economically interdependent and between those that were minimally so. Three major sources of tension were at the root of these crises, and each was exacerbated by changes in the balance of power. The first source of tension was Germany's occupation of Lorraine and (to a lesser degree) Alsace, both captured from France during the Franco-Prussian War. To many in France, relations with the Reich could not be normal so long as these territories remained in German hands. A second source of tension involved the competing colonial ambitions of the major powers. Few territories were left to conquer, even as Germany increased its drive for colonial expansion after unification. Finally, after decades of decline, the Ottoman Empire no longer possessed the strength to maintain dominance over its European possessions. This, and the accompanying rise of Balkan nationalism, threatened not only Turkey's interests but also those of the other powers in the region, especially Austria-Hungary and Russia. 
Changes in the balance of power, and the competing ambitions associated with them, led to frequent clashes among European states, but these disputes generally did not escalate to war when conflicts involved states that were economically interdependent. To begin with, despite the bitter rivalry between France and Germany, the two powers remained at peace for more than forty years after the Treaty of Frankfurt. What makes the era so remarkable is that both nations spent these decades girded for war, having created, established, and maintained elaborate plans for invading each other.

Significantly, the competition for colonies among the European powers led to a series of crises. It should be noted that it was the interdependent Western powers that featured most prominently in the struggle for colonial empire. Yet, none of these crises resulted in a European war. Britain and France, long-time rivals both on the continent and in terms of their global possessions, experienced two near-war crises during this era. In 1893 France sent gunboats to Bangkok to demand that Siam cede a large portion of its territory (most of which later became Laos). Siam, a British client state, requested support from London. Rather than backing its protégé against its chief historical adversary, Britain prevailed on the Siamese to cede the disputed region to the French. In return, France promised to make no future demands for additional territory in the region, relieving the danger of future disputes among the interdependent European powers at the expense of English prestige and French ambition. Again, in 1898 Britain and France nearly went to war, this time as a result of the Fashoda crisis. A standoff between the two countries was caused by competing attempts to extend their spheres of influence in East Africa. After several months, the French withdrew their troops, and the governments agreed on a division of the region among themselves, ending the last major source of colonial tensions between them. ${ }^{44}$ In both crises, one of the major powers backed down or declined to intervene, apparently deciding that war was not worth the cost.

Tensions between France and Germany were also heightened by colonial competition. First, in 1905, Kaiser Wilhelm I visited Tangier and gave a speech promoting Moroccan independence, provoking the French authorities. France moved troops to the German border while Germany called up its reservists, but the crisis was resolved through an international conference before it became highly militarized. The Germans reluctantly backed down in humiliation when only Austria-Hungary supported their position. As David Herrmann writes, "The Moroccan confrontation . . . marked the beginning of a series of 
diplomatic trials of strength that continued until the outbreak of World War I, each escalating from its predecessor and helping to drive the European powers into two opposing and increasingly armed camps." ${ }^{\prime 4}$ A second serious Moroccan crisis erupted in 1911 when Germany sent the gunboat Panther to Agadir in response to France's attempt to take full control of Morocco by advancing 15,000 troops to Fez. Even if the war could be contained, its effects on European commerce and capital flows could be catastrophic, as many in Europe recognized. Again, the European powers negotiated, and again the Germans backed down. Neither the kaiser nor German Chancellor Theobald von Bethmann-Hollweg was interested in war over Morocco. L.C.F. Turner writes that three factors contributed to this decision: (1) the German navy was relatively weak and could not take on the French, who were supported by the British; (2) neither Austria-Hungary nor Russia had a significant interest in Morocco, allowing the conflict to be settled among the three Western powers; and (3) "French withdrawal of short-term loans from the Berlin market led to heavy falls on the stock exchange and demands from German financiers for a lessening of tension." 46 The latter factor provides a strong indication that close economic relations between France and Germany contributed to preventing war. As Stevenson notes, "[O]nce Wilhelm II had ruled that war must be avoided, Germany again accepted a diplomatic setback in preference to provoking hostilities or to bluffing." 47

Disputes between the other interdependent powers were also generally resolved peacefully during this period. For example, in the Dogger Bank incident during the Russo-Japanese War, the Russian navy fired on several British fishing boats in the North Sea, mistaking them for Japanese men-of-war after receiving false reports of a Japanese naval presence in the area. Although, as Joachim Remak argues, "[I]f some sort of apparatus for the measurement of hostility between nations were to exist, Anglo-Russian relations, in the half century or so before 1904, might receive its highest score," ${ }^{48}$ the British chose not to retaliate. This decision is particularly striking given that the British were formally in alliance with the Japanese (although Britain was not committed to providing support unless Japan became involved in a conflict with two other

45. David G. Herrmann, The Arming of Europe and the Making of the First World War (Princeton, N.J.: Princeton University Press, 1996), p. 37. See also Stevenson, "Militarization and Diplomacy in Europe before 1914"; Jeffrey W. Taliaferro, Balancing Risks: Great Power Intervention in the Periphery (Ithaca, N.Y.: Cornell University Press, 2004), pp. 55-93; and Richard F. Hamilton, "The European Wars: 1815-1914," in Hamilton and Holger H. Herwig, eds., The Origins of World War I (Cambridge: Cambridge University Press, 2003), p. 85.

46. L.C.F. Turner, Origins of the First World War (New York: W.W. Norton, 1970), p. 19.

47. Stevenson, "Militarization and Diplomacy in Europe before 1914," p. x.

48. Joachim Remak, The Origins of World War I: 1871-1914 (Hinsdale, Ill.: Dryden, 1967), p. 40. 
powers). Had the British retaliated, leading to a war with Russia, we can easily imagine many analysts calling such a war "inevitable" in retrospect. Similarly, although the British-German rivalry grew in intensity during this period, fueled partly by Germany's post-unification ambitions for colonial empire, this rivalry did not result in war until 1914. On multiple other occasions-most notably, the Boer War, in which Germany chose to remain neutral-disputes that could well have led to a general war were resolved peacefully.

Why, then, did these powers, which had motives for war along with detailed plans for fighting, refrain from doing so for several decades? There were likely many causes of the enduring peace among these powers. Economic relations were a key factor in maintaining the peace. A.J.P. Taylor notes that " $[t]$ he decisive cause was, no doubt, economic. The secret that had made Great Britain great was a secret no longer. Coal and steel offered prosperity to all Europe and remade European civilization. The dream of Cobden seemed to have come true. Men were too busy growing rich to have time for war." ${ }^{49}$ Arguing against the Marxist hypothesis that economic interests make war more likely, Niall Ferguson notes that "there is scarcely any evidence that these interests made businessmen want a major European war." ${ }^{50}$ In addition, he points out that "[i]f there was a war which imperialism should have caused it was the war between Britain and Russia which failed to break out in the 1870s and 1880s; or the war between Britain and France which failed to break out in the 1880s or 1890s." ${ }^{51}$ Others go further, arguing that business interests actively opposed war. Remak writes that "divergent national interests in the field of commerce did not make for armed conflict; in times of crisis, 1914 included, businessmen on all sides were among the strongest advocates of peace." ${ }^{52}$ Likewise, Richard Hamilton argues that "[i]f business had been dominant, if 'the bourgeoisie' had been in power, the war would not have happened." 53

Relations between France and Germany provide a useful illustration. During this era, finance and manufacturing became highly integrated; levels of trade grew significantly; and unprecedented amounts of capital flowed across their borders. A key example is the German finance of iron mining in the French region of Longwy-Briey (a region the Germans later controlled during

49. A.J.P. Taylor, The Struggle for Mastery in Europe, 1848-1918 (Oxford: Oxford History of Modern Europe, 1954), p. 255.

50. Niall Ferguson, The Pity of War: Explaining World War I (New York: Basic Books, 1999), p. 32.

51. Ibid., p. 39.

52. Joachim Remak, "The Third Balkan War: Origins Reconsidered," in Hannsjoachim W. Koch, ed., The Origins of the First World War: Great Power Rivalry and German War Aims, 2d ed. (London: Macmillan, 1984), p. 87.

53. Richard F. Hamilton, "On the Origins of the Catastrophe," in Hamilton and Herwig, The Origins of World War I, pp. 469-506, at p. 469. 
the war to their strategic advantage). As Turner notes, "[S]o far from being bitter rivals French and German capitalists were happy to cooperate." ${ }^{54}$ Neither nation was willing to concede key claims against the other; France wanted its northeastern territories returned, and Germany was tired of being shut out of colonial expansion. Still, neither would sacrifice mutual economic benefits to pursue these disputed objectives, at least not through direct confrontation and not as isolated issues.

Other factors could have encouraged peace among the integrated powers during this era. For example, it could be claimed that the integrated powers had strategic incentives to capitalize on peace. As beneficiaries of the status quo, perhaps Britain and France were simply seeking to perpetuate conditions experienced in the Concert of Europe. Yet, if some Western nations were also status quo powers, other integrated nations were revisionists. Germany was unhappy with its limited allocation of colonies, for example, while Russia was distressed with the treatment of its allies by Austria-Hungary. Even Britain and France had differences in other regions, if not in Europe directly. Indeed, Austria-Hungary demonstrates that a desire to maintain the conditions that had brought peace in a previous epoch may well have exacerbated tensions in the decades before World War I. The integrated powers of Europe responded differently to the important tensions that did arise, whereas nonintegrated powers in the same region reacted with force. The strategic argument thus begs the question of why the highly integrated powers exhibited a preference for peace, regardless of their status quo or revisionist preferences, but the less interdependent powers, as shown below, did not. Maintaining the view that strategic preferences accounted for peace before 1914 also requires explaining why these preferences changed in 1914. Indeed, any theory of the prewar peace must account for the changes that resulted in war in 1914. In the section "The 1914 Crisis," we explain what was different in 1914 in a manner that is both consistent with the pacific effects of economic relations, but also suggests that the relationship between commerce and conflict is more nuanced than many theories suggest.

THE WEAKLY INTERDEPENDENT SUBSYSTEM

As the interdependent powers set a pattern of peace, other European states often escalated their disputes to war, particularly in the Balkans. The underlying reason for the tension in the Balkans during this era was the rapid decline of the Ottoman Empire, which, accompanied by the rise of nationalism in the region, led many Balkan nations to seek independence. In addition to Turkey's 
interest in maintaining its European possessions, Russia and Austria-Hungary also had key strategic interests in the region. Russia generally supported the rise of Balkan nationalism because of its long-time rivalry with Turkey, its ambitions for access to the Mediterranean, and the influence of pan-Slavism in Moscow. The multinational Austria-Hungary, however, was threatened by rising Balkan nationalism and faced a security dilemma, especially with respect to Serbia. ${ }^{55}$ As L.L. Farrar writes, "[W] hat would preserve Austria-Hungary as a great power would provoke Serbian nationalism, and what would satisfy Serbian nationalism would threaten Austria-Hungary as a great power. Thus coexistence seemed virtually impossible and conflict almost inevitable."56 Again, however, what appears inevitable in retrospect may have been less so in practice. If there was much to impel conflict in the Balkans, there was also a considerable basis for clashes among the Western powers, as we have already discussed. There were strong motives for war both in the West and in the Balkans; what seems distinct about the Balkans was the general absence of a positive motive for peace. Lacking the commercial incentives to cooperate that saturated relations in the West, Eastern nations were prone to see the strategic calculus as zero sum.

Other countries participated in driving or mediating festering Balkan disputes, a process that increasingly enmeshed the foreign policies of European powers with their Balkan protégés. Nations outside the region began to "tie their hands" with alliance commitments to bolster the leverage of Balkan partners. Ironically, the great German statesman Otto von Bismarck made it clear that Germany's interests in the region were decidedly limited: "For us, Balkan questions can never be a motive for war." ${ }^{\prime 57}$ Yet, the reputations of foreign powers seemed increasingly to be tied to their actions in the region, even as discretion over wider European foreign policy was increasingly handed over to local officials through tightening alliance commitments.

Several conflicts in the late nineteenth century exhibited the tendency of crises to escalate to warfare in the region. Early conflicts included the Serbian and Montenegrin war of independence against Turkey in 1876, the Russo-Turkish War in 1878, the Serbo-Bulgarian War in 1885, and the Greco-Turkish War in 1897. In the direct lead-up to World War I, the first crises of note were the Pig War between Serbia and Austria-Hungary, followed by the Bosnian annex-

55. Benjamin Miller and Korina Kagan, “The Great Powers and Regional Conflicts: Eastern Europe and the Balkans from the Post-Napoleonic Era to the Post-Cold War Era," International Studies Quarterly, Vol. 41, No. 1 (March 1997), pp. 51-85.

56. L.L. Farrar Jr., "The Limits of Choice: July 1914 Reconsidered," Iournal of Conflict Resolution, Vol. 16, No. 1 (March 1972), pp. 1-23, at p. 10.

57. Quoted in Remak, The Origins of World War I, p. 14. 
ation crisis. After Serbia increased French imports and created a customs union with Bulgaria, Austria-Hungary responded in 1906 by refusing to import Serbian livestock. Serbia found markets elsewhere, consequentially dramatically reducing Austro-Serbian trade, ${ }^{58}$ which, in turn, meant that trade was unlikely to prevent war between the two states.

The Pig War also led to Austria-Hungary's decision in 1908 to annex Bosnia and Herzegovina, both of which it had administered under the 1878 Treaty of Berlin. Serbia had sought to use Bosnia and Herzegovina as an outlet to the Adriatic in large part to overcome the Austro-Hungarian blockade of Serbian goods. Austrian annexation understandably threatened both Russia, which would have preferred that the territories remain independent, and Serbia, which preferred them to be Serbian. Russia, still recovering from its war with Japan, was in no position to fight. ${ }^{59}$ Russian officials actually took the extraordinary step of informing the Austrians of their intention not to intervene even if Austria-Hungary occupied Belgrade. ${ }^{60}$ Germany notified Russia that it would declare war on Russia and France in the event of Russian mobilization. As a result, Russia backed down, forcing Serbia to withdraw its protest of the annexation. Annika Mombauer writes that "[g]iven the fact that Germany gave unconditional support for Austria-Hungary over this Balkan matter, it was primarily Russia's mediating influence on Serbia that prevented war on this occasion." 61

The Bosnian crisis is notable for at least three reasons. First, Russia suffered a significant humiliation by backing down, both in the eyes of the major powers and with respect to Serbia, which began to doubt Russia's support for its ambitions. ${ }^{62}$ Second, this crisis, like that of Morocco in 1905, indicated to participants that the side showing greater resolve got its way. ${ }^{63}$ Indeed, Germany could reasonably draw the conclusion that, if it committed to war, Russia was likely to back down, and conflict would be averted. Third, the crisis is an example of conflict between the Triple Alliance and the Triple Entente being courted by Austria-Hungary rather than by Germany. As Laurence Lafore ar-

58. Richard C. Hall notes that the Pig War "ended Serbian economic dependence on AustriaHungary." Hall, "Serbia," in Hamilton and Herwig, The Origins of World War I, p. 92.

59. G.J. Meyer, A World Undone: The Story of the Great War, 1914 to 1918 (New York: Bantam Dell, 2006), pp. 21-22; and Herrmann, The Arming of Europe and the Making of the First World War, pp. 117-122.

60. Stevenson, “Militarization and Diplomacy in Europe before 1914," p. 135.

61. Annika Mombauer, The Origins of the First World War: Controversies and Consensus (London: Pearson Education, 2002), p. 10

62. Remak, The Origins of World War I, p. 48; and Ronald Bobroff, "Behind the Balkan Wars: Russian Policy toward Bulgaria and the Turkish Straits, 1912-13," Russian Review, Vol. 59, No. 1 (January 2000), pp. 76-95.

63. Stevenson, "Militarization and Diplomacy in Europe before 1914," p. 135. 
gues, the Dual Alliance tied Germany "to a state whose future involved securities of a very different kind from Germany's." ${ }^{64}$ This point is crucial as it demonstrates that Germany's foreign policy was becoming increasingly tied to that of Austria-Hungary. ${ }^{65}$

The immediate consequence of rising tensions in the Balkans was a pair of regional wars fought in 1912 and 1913. In 1912 a coalition made up of Bulgaria, Greece, Montenegro, and Serbia declared war on Turkey, seeking to drive the Turks out of Europe. Many observers in Europe predicted the conflict would spread to the rest of the continent, especially because Austria-Hungary was expected to intervene in an effort to repel Serbia from the Sanjak of Novibazar, a region it had previously administered under the Treaty of Berlin and which Serbia captured from the Ottomans during the fighting. Similarly, Russia was expected not to back down, as it had earlier in the Bosnian crisis. ${ }^{66}$

A general war was again averted, this time because Germany declined to support Austria-Hungary's ambitions and because Russia eventually also backed down. At first, Russia mobilized forces along its Western frontier (although Russia claimed this was unrelated to the war). In Germany, however, the leadership, apparently maintaining Bismarck's disinterest in the Balkans, decided not to support Austria-Hungary. Once the Germans made their decision, the Russians also withdrew, perhaps in part because Germany's abandonment of Austria-Hungary allowed Russia to back down while still saving face. Thus, despite an interest in avoiding further humiliation, the Russians told the French that "even if Austria should attack Serbia, Russia will not fight." 67

A similar crisis arose in 1913 when the winners of the First Balkan War fought over the spoils captured in the previous conflict. Specifically, Bulgaria, Greece, and Serbia each fought for a greater share of Macedonia, with the war later expanding to include Montenegro, Romania, and the Ottoman Empire. Austria-Hungary, threatened again by the specter of Slavic nationalism, reacted slowly to unfolding events, but eventually mobilized troops along the Serb and Russian borders. Once again, the conflict was prevented from spread-

64. Laurence Lafore, The Long Fuse: An Interpretation of the Origins of World War I (London: Weidenfeld and Nicolson, 1966), p. 97.

65. On the Bosnian crisis generally, see ibid., pp. 151-159; Remak, The Origins of World War I, pp. 46-48; and Stevenson, "Militarization and Diplomacy in Europe before 1914."

66. Lafore, The Long Fuse, p. 170. James Joll notes that "failure to support Serbia again would mean, the Russians thought, the end of Russian prestige in the Balkans and the beginning of a possible new diplomatic alignment there." Joll, The Origins of the First World War, p. 55.

67. Quoted in William C. Wohlforth, "The Perception of Power: Russia in the Pre-1914 Balance," World Politics, Vol. 39, No. 3 (April 1987), pp. 353-381, at p. 359. Turner also argues, "It therefore appears that if Russia had resorted to military measures in support of Serbia's claim to an Adriatic port then a world war would have broken out in 1912." Turner, Origins of the First World War, p. 43. 
ing through the diplomacy of the interdependent states. James Joll argues that Britain was successful in negotiating the end of the conflict and the independence of Albania because, "to the annoyance of the Austrians, the Germans decided that they would not put their whole weight behind the Austrian efforts to limit Serbia's gains." 68

The two Balkan Wars are significant for several reasons relevant to the outbreak of war in 1914. First, building on the earlier conflicts in the region, they showed that Balkan disputes were generally settled by fighting, a pattern far different from that of the interdependent powers. Indeed, the interdependent powers were often critical in mediating disputes and in helping to terminate recurrent regional wars. Second, the cycle of Balkan conflicts showed the potential for small, less interdependent states to exploit security relationships with more interdependent allies. Alliances pose the risk that a state may be entrapped into war. ${ }^{69}$ Balkan states used to their advantage the rivalry between Austria-Hungary and Russia, as well as the desire of Britain, France, and Germany to avoid a major war. ${ }^{70}$ Third, the crises showed that Germany and Russia were the pivotal states in the alliance system; their decisions on whether or not to support their smaller allies were the key to limiting or expanding the size of wars. ${ }^{71}$ Joll notes that "the Balkan quarrels had not escalated into a European war because the Germans were not prepared to give their ally a free hand against Serbia." ${ }^{12}$ Yet the crises did not escalate because the Russians also appeared willing to back down in certain situations. Fourth, the Balkan Wars continued a trend of increasingly militarized conflicts in which the more militarized side was regularly the winner. This encouraged

68. Joll, The Origins of the First World War, p. 52. See also Sean M. Lynn-Jones, “Détente and Deterrence: Anglo-German Relations 1911-1914," International Security Vol. 11, No. 2 (Fall 1986), pp. 121-150; and Meyer, A World Undone, p. 25.

69. See, for example, Thomas J. Christensen and Jack Snyder, "Chain Gangs and Passed Bucks: Predicting Alliance Patterns in Multipolarity," International Organization, Vol. 44, No. 2 (Spring 1990), pp. 137-168; and David A. Lake, Entangling Relations: American Foreign Policy in Its Century (Princeton, N.J.: Princeton University Press, 1999). For a similar argument, see Glenn H. Snyder, “The Security Dilemma in Alliance Politics," World Politics, Vol. 36, No. 4 (July 1984), pp. 461-495.

70. Samuel R. Williamson Jr. has argued that Austria-Hungary used the assassination of Archduke Franz Ferdinand as a pretext for pulling Germany into a war with Serbia. Williamson, "Influence, Power, and the Policy Process: The Case of Franz Ferdinand," Historical Journal, Vol. 17, No. 4 (June 1974), pp. 17-34; and Williamson, "The Origins of World War I," Iournal of Interdisciplinary History, Vol. 18, No. 7 (Spring 1988), pp. 795-818. Graydon A. Tunstall Jr. provides evidence that AustriaHungary wanted a war, although a limited one, with Serbia. Turnstall, "Austria," in Hamilton and Herwig, The Origins of World War I, pp. 112-149. See also Remak, The Origins of World War I, p. 63. 71. Holger H. Herwig, The Marne, 1914: The Opening of World War I and the Battle That Changed the World (New York: Random House, 2009), pp. 3-73; Joll, The Origins of the First World War, p. 53; and Annika Mombauer, "German War Plans," in Richard F. Hamilton and Holger H. Herwig, War Planning 1914 (Cambridge: Cambridge University Press, 2010), pp. 48-79.

72. Joll, The Origins of the First World War, p. 53. 
leaders on all sides to use brinkmanship tactics and to adopt commitment mechanisms, such as ever tighter alliance ties, in the hope that their opponents would be the ones to back down. ${ }^{73}$

Taken together, these effects of the Balkan Wars created increasing incentives for the great powers to solidify their alliance relationships in the region. The European alliance system was arguably created by the great powers as a deterrent to reduce the likelihood of war. This was the case beginning with the Bismarckian system created in the 1870s and 1880s, which was designed to protect the newly unified Germany from its neighbors, but also with the Triple Alliance and Triple Entente, designed in part to deter each other. The dilemma facing the great powers in the early twentieth century was how to effectively signal their resolve to fight as a means to deter the other side.

Winning at the game of Chicken involves commitment. To increase their resolve, great powers such as Germany and Russia were increasingly forced to limit their options in crisis situations. ${ }^{74}$ As Thomas Schelling explains, decisionmakers in a crisis can improve expected payoffs by constraining their ability to act with discretion. ${ }^{75}$ German and Russian leaders tied their hands in two ways during this era. First, they increasingly ceded decisionmaking authority to the military by putting in place processes that, once an initial decision was made to begin hostilities, made it costly for civilian leaders to back down. As a result, Joll writes, "[T]he general staffs were taking decisions which often committed them to irreversible military actions if war threatened: and consequently in a crisis the freedom of action of the civilian ministers was often more circumscribed than they themselves realized." ${ }^{\prime 76}$ The second way in which German and Russian leaders limited their options was by tightening alliance commitments. For example, after failing to support its ally in the Second Balkan War, G.J. Meyer argues that German policy was that "[n]ever again must Vienna have reason to doubt the value of its alliance with Germany."77 The effect of tightening alliances, however, was that of "chain-ganging." Tighter alliance commitments allowed the weaker partner to draw on the power of the stronger partner in crisis bargaining, thereby increasing the prospects for diplomatic success.

This leverage, however, also increased the hazard that a great power would

73. Many historians and political scientists have referred to crisis bargaining during this period as a game of brinkmanship. See, for example, Sagan, "1914 Revisited"; Remak, "The Third Balkan War," p. 95; and Stevenson, "Militarization and Diplomacy in Europe before 1914," p. 155.

74. For a similar argument, see Farrar, "The Limits of Choice."

75. Thomas C. Schelling, The Strategy of Conflict (Cambridge, Mass.: Harvard University Press, 1960).

76. Joll, The Origins of the First World War, p. 56.

77. Meyer, A World Undone, p. 25. 
be drawn into a larger dispute. John Maurer notes, for example, that "[i]t was clear to Russian decision makers that a confrontation with Austria-Hungary entailed running the high risk of conflict with Germany." ${ }^{\prime 78}$ Attempting to increase the leverage of their allies, the interdependent powers gradually signed over their foreign policies to their allies in the Balkans, which lacked both economic ties and interests in maintaining a wider peace in Europe. As a result, German and Russian leaders faced an increasingly difficult choice between honoring alliance commitments and losing credibility in European affairs. The former put in jeopardy the trade and capital networks that now fueled their increasingly destructive military machines, while the latter threatened to nullify their ability to achieve gains diplomatically, without the need to use force. Credibility and support for their partners required increasingly binding commitments, but these in turn created increasingly diametric alternatives for the integrated powers. Backing down meant suffering increasing reputational costs, whereas failing to do so required that their counterparts would suffer a similar fate. Ironically, interdependence accentuated this logic, as the high stakes for a contest and previous experience convinced both sides that their opponents would blink first. Again and again, Balkan crises failed to spread as either Germany or Russia chose to back down. This reassured the interdependent powers that the European system was robust to such crises and that, in future crises, someone (else) would act with greater discretion.

We thus offer three main points about the period between the FrancoPrussian War and World War I. First, disputes among the highly interdependent powers were generally resolved peacefully in the pre-World War I era. Second, disputes among the less interdependent powers generally escalated to wars, except where the (interdependent) great powers saw it in their interests to intervene to mediate disputes and prevent them from drawing in other powers. Finally, as a result of a series of crises, leaders in Germany and Russia, the pivotal states in the alliance system, increasingly found the need to bind their fates, and the fate of Europe, to that of their allies Austria-Hungary and Serbia. That a general war did not break out before 1914 is, in many ways, attributable to German and Russian decisions to back down rather than to support regional allies. This in turn led to excessive confidence that wider war would be averted, in no small part because all involved recognized the mutual economic benefit of avoiding a wider contest.

78. John H. Maurer, The Outbreak of the First World War: Strategic Planning, Crisis Decision Making, and Deterrence Failure (Westport, Conn.: Praeger, 1995), p. 72. 


\section{The 1914 Crisis}

In 1912 and 1913, Germany and Russia averted war. Why did 1914 end differently? Although the conflict-reducing effects of interdependence may have subsided with growing tensions on the continent, this in itself is a tacit acknowledgment that interdependence inhibits conflict, at least for a while. Both Germany and Russia honored their alliance commitments to the point of starting a general war. German support for Austria-Hungary enabled the latter's action against Serbia, and the war would not have spread were it not for Russian intervention. ${ }^{79}$ The question then becomes why Germany and Russia made these decisions in 1914. Scholars have spent the better part of a century analyzing the decisions that turned the crisis into a world war. Our aim here is not to conduct such an analysis, but to interpret the sequence of events in terms of the logic of escalation and crisis bargaining.

Two points are worth making. First, the series of crises leading to the war created incentives for the key players, Germany and Russia, to appear willing to escalate to a wider war, if necessary, in support of their Balkan allies. This, in turn, increased uncertainty; both German and Russian officials had reason to suspect that their counterparts might be bluffing. Second, the pacific effects of interdependence had important consequences for crisis bargaining. Germany and Russia each attempted to convince the other that it must back down by showing increasing resolve to support its less interdependent ally. AustriaHungary and Serbia had weaker economic disincentives to go to war, which is precisely what made these tightening alliance commitments stronger signals of resolve. Indeed, the need to forge ever tighter alliance ties may be explained in part by the disincentives that interdependence posed for both threatening and carrying out major war. ${ }^{80}$

\footnotetext{
79. Gary Goertz and Jack S. Levy, “Causal Explanation, Necessary Conditions, and Case Studies,” in Goertz and Levy, eds., Explaining War and Peace: Case Studies and Necessary Condition Counterfactuals (New York: Routledge, 2007); Luigi Albertini, The Origins of the War of 1914, Vol. 2 (London: Oxford University Press, 1957), p. 162; David Stevenson, Cataclysm: The First World War as Political Tragedy (New York: Basic Books, 2004), pp. 13-14; Hall, "Serbia," pp. 92-111; Hew Strachan, The First World War (London: Penguin, 2005), p. 12; Maurer, The Outbreak of the First World War, p. 115; Meyer, A World Undone, p. 33; and Richard Ned Lebow, "Contingency, Catalysts, and Nonlinear Change," in Goertz and Levy, Explaining War and Peace, p. 102.

80. On the relationship among trade, alliances, and conflict, see Brian M. Pollins, "Does Trade Still Follow the Flag?" American Political Science Review, Vol. 83, No. 2 (June 1989), pp. 465-480; Joanne Gowa and Edward D. Mansfield, "Power Politics and International Trade," American Political Science Review, Vol. 87, No. 2 (June 1993), pp. 408-420; James D. Morrow, Randolph M. Siverson, and Tressa E. Tabare, "The Political Determinants of International Trade: The Major Powers, 1907-90," American Political Science Review, Vol. 92, No. 3 (September 1998), pp. 649-661; and Quan Li and
} 
Europe in 1914 thus reveals a nuanced relationship between interdependence and the likelihood of war. The logic of commercial peace finds significant support in the crisis bargaining witnessed in Europe leading up to the war. At the same time, economic disincentives for war also led to military integration designed in part to overcome these very same disincentives. Alliance ties formed and strengthened between highly and weakly interdependent powers led to decisionmaking that appeared to overlook economic ties, as weakly interdependent powers were given increasing influence over the foreign policies of nations that, by themselves, preferred commerce to conflict.

A few aspects of the game of Chicken that characterizes the crises leading up to World War I are worthy of additional attention. ${ }^{81}$ There are two purestrategy Nash equilibria in a standard two-player game of Chicken: one in which player A swerves and one in which player B swerves. ${ }^{82}$ Yet, these equilibria assume that players are fully informed about what the other will do. The assumption of full information is inconsistent with the larger logic of brinkmanship and tying-hands commitments through alliances. If the players are uncertain about each other's intentions, then a more complex set of outcomes is possible. If, for example, A overestimates B's willingness to swerve, then the worst possible outcome can ensue. ${ }^{83}$ With incomplete information, equilibria can occur in the game of Chicken in which neither player swerves, as it seems happened with Germany and Russia in 1914.

More generally, the iterated game of Chicken played by Germany and Russia leading up to the war created increased incentives to convince the other to back down by signaling a resolve to fight. Having learned in previous crises that the other could be brought to heel, especially in the face of firm resolve, each state was intent on pushing the other to its limit. ${ }^{84}$ Austrian leaders believed that giving Serbia an ultimatum supported by Germany would reduce the risk of Russian intervention. ${ }^{85}$ The kaiser, in a change in policy from the Balkan Wars, decided to support Austria-Hungary unconditionally, recogniz-

David Sacko, "The (Ir)Relevance of Militarized Interstate Disputes for International Trade," International Studies Quarterly, Vol. 46, No. 1 (March 2002), pp. 11-43.

81. For a contrary view, see Stephen Van Evera, “Why Cooperation Failed in 1914," World Politics, Vol. 38, No. 1 (October 1985), pp. 80-117.

82. Anatol Rapoport and Albert M. Chammah, "The Game of Chicken," American Behavioral Scientist, Vol. 10, No. 10 (November 1966), pp. 10-28. A mixed-strategy Nash equilibrium exists where each player swerves with some probability.

83. Glenn H. Snyder, "'Prisoner's Dilemma' and 'Chicken' Models in International Politics," International Studies Quarterly, Vol. 15, No. 1 (March 1971), pp. 66-103.

84. Stevenson, "Militarization and Diplomacy in Europe before 1914." Advances in military mobilization logistics also enabled leaders to generate ever greater risks using brinkmanship tactics. Beckett, The Great War, p. 29.

85. Williamson, "The Origins of World War I," p. 810; and Joll, The Origins of the First World War, p. 21. 
ing that failure to do so risked the destruction of the alliance. ${ }^{86}$ As Jack Levy notes, "German decision-makers hoped and expected that an Austrian fait accompli against Serbia in the immediate aftermath of the royal assassination, backed by German warnings to Russia, would minimize the likelihood of Russian intervention." 87 German Foreign Minister Gottlieb von Jagow famously remarked that "the more determined Austria shows herself, the more energetically we support her, so much the more quiet Russia will remain." 88 Prior to the assassination of Archduke Franz Ferdinand, the kaiser met with and urged Austria-Hungary to go to war with Serbia, believing that Russia would stay out of the fight. ${ }^{89}$

Russian officials were convinced that Germany and Austria would relent if pushed far enough. Having already experienced defeat in both the RussoJapanese War and the 1908-09 Bosnian crisis, Russia did not want to appear weak again. ${ }^{90}$ Vigorous Russian support, in turn, strengthened Serbian resolve. ${ }^{91}$ As Joll puts it, "[T]he Austrians had believed that vigorous actions against Serbia and a promise of German support would deter Russia: the Russians had believed that a show of strength against Austria would both check the Austrians and deter Germany. In both cases the bluff had been called, and the three countries were faced with the military consequences of their actions." 92

Russia mobilized first, and Germany responded by declaring war. Historians have debated the reasoning for Germany's decision for decades, mostly famously following Fritz Fischer's argument that Germany courted the war and was largely responsible for it. ${ }^{93}$ We will certainly not settle this complex and enduring debate here, but we can perhaps contribute two points.

86. Farrar, "The Limits of Choice," p. 11.

87. Levy, "Preferences, Constraints, and Choices in July 1914," p. 160; and Stephen Van Evera, "The Cult of the Offensive and the Origins of the First World War," International Security, Vol. 9, No. 1 (Summer 1984), pp. 58-107.

88. Quoted in Imanuel Geiss, The Outbreak of the First World War: Selected Documents (New York: W.W. Norton, 1967), p. 123. Holger H. Herwig refers to German actions in 1914 as a "game of bluff." Herwig, "Germany," in Hamilton and Herwig, The Origins of World War I, p. 177.

89. David Stevenson, The First World War and International Politics (Oxford: Oxford University Press, 1988), pp. 25-26. See also Strachan, The First World War, p. 14.

90. D.C.B. Lieven, Russia and the Origins of the First World War (New York: St. Martin's, 1983); Joll, The Origins of the First World War, p. 55; William R. Thompson, "A Streetcar Named Sarajevo: Catalysts, Multiple Causation Chains, and Rivalry Structures" International Studies Quarterly, Vol. 47, No. 3 (September 2003), pp. 453-474; and Remak, The Origins of World War I, p. 136.

91. Stevenson, "Militarization and Diplomacy in Europe before 1914."

92. Joll, The Origins of the First World War, p. 21. See also Lafore, The Long Fuse, p. 233.

93. On the Fischer controversy, see, generally, Koch, The Origins of the First World War; Mombauer, The Origins of the First World War; and Matthew Stibbe, "The Fischer Controversy over German War Aims in the First World War and Its Reception by East German Historians, 1961-1989," Historical Journal, Vol. 46, No. 3 (September 2003), pp. 649-668. 
First, to the extent that Germany appeared to be pushing Austria-Hungary toward war, our argument suggests that Germany may have done so not because it sought war but because it sought to convince Russia to back down. Second, once Russia had mobilized, Germany's options were perhaps quite limited. If a major power war were to be fought, Germany preferred that it be fought immediately rather than waiting for the French and Russians to have more time to mobilize. ${ }^{94}$ As Meyer points out, "An open-ended postponement of hostilities ... would have destroyed Germany's chances of defeating France before having to fight Russia." 95 Indeed, as James Fearon argues, "[P]art of what made the Russian mobilization in 1914 an informative signal of Russia's willingness to fight was that it was under-taken in the knowledge that it would increase Germany's incentive to choose preemptive war." 96 Thus, that the kaiser opted for war in July 1914 may not indicate that Germany had a preference for war (which would be damaging to commercial liberal theory). Rather, it may indicate that Germany opted for a war that seemed the best of limited options. Third, the notion that the war happened primarily because Germany wanted it is difficult to reconcile with theory. If wars result from asymmetric information, then it may have been the case that if Germany had better information, it would not have wanted to go to war. In addition, to the extent that the war was the result of commitment problems, it could be argued that a Germany in decline would have a preference for war because its rivals could not commit to refrain from attacking Germany later. Yet Germany during this era was a rising, rather than declining, power.

To be clear, it was far from inevitable that both Germany and Russia would back their allies in 1914. It was entirely possible that at least one patron would back down again, as had happened previously. Yet, each succeeding crisis increased the incentive for Germany and Russia to heighten their commitments, adding to the cost of backing down and increasing the danger of war. Interdependence could have reduced the likelihood of a major contest. Arguably it did, which paradoxically caused the interdependent powers to seek more credible ways to backstop the demands of their Balkan allies. Less inter-

94. Ferguson, The Pity of War, p. 153; David Stevenson, Armaments and the Coming of War (Oxford: Clarendon, 1996), p. 418; Herrmann, The Arming of Europe and the Making of the First World War, pp. 227-228; and Annika Mombauer, Helmuth von Moltke and the Origins of the First World War (New York: Cambridge University Press, 2001), pp. 203-204. Keir Lieber provides a different argument: "The newest evidence about decision making during the July crisis, however, suggests that German leaders did not lose control of events on the eve of war, but rather capitalized on what they viewed as a golden opportunity to start the war they wanted." Lieber, "The New History of World War I and What It Means for International Relations Theory," p. 184.

95. Meyer, A World Undone, p. 93.

96. James D. Fearon, "Domestic Political Audiences and the Escalation of International Disputes," American Political Science Review, Vol. 88, No. 3 (September 1994), pp. 577-592, at p. 580. 
dependent than their patrons, Austria-Hungary and Serbia had weaker disincentives for going to war. Given rising attachment to globalization, adding credibility to Russia's and Germany's claims required delegating significant decisionmaking authority to Serbia and Austria. As a result of these incentives, the highly interdependent European subsystem became increasingly entangled with the less interdependent European subsystem through alliance ties.

A wider war may still have been avoided, even with Germany and Russia committed to an expanded Balkans conflict. Most important, Britain and France had not yet joined the war. The question remained whether they, too, would honor their alliance commitments. ${ }^{97}$ At least one determinant of the conflict may have been the ambiguity of the British position on intervention and the German assumption that Britain would remain neutral, in part to protect its commerce. ${ }^{98}$

There is even evidence that the relationship between interdependence and conflict remained in effect during the war. Consider the European states that were convinced to enter the war after August 1914: Bulgaria, Greece, Italy, Portugal, Romania, and Turkey. Although each joined the war for different reasons, with the possible exception of Italy none of these states was significantly interdependent before the war began. Italy entered the war because of significant territories offered it in Libya, Eritrea, and Somaliland, suggesting that a large offer such as this may have been required to outweigh the importance of other economic concerns. Furthermore, although less attention is paid to the European states that remained neutral, it is worth noting that among these were Denmark, the Netherlands, Norway, and Sweden-all highly economically interdependent states. Denmark deserves particular attention because it had fought wars with Germany in the nineteenth century and the sovereignty of Southern Jutland was unresolved, so a salient dispute existed between the two countries. Yet, as Bent Bludnikow notes, Denmark maintained its neutrality "to be able to enjoy the advantages of its extensive international trade and shipping." 99 The Netherlands, whose neutrality was not a foregone conclusion, also chose to remain neutral for economic reasons. ${ }^{100}$ Thus, a pattern

97. Remak notes that "if, for instance, the Austrians had been certain beyond a doubt that an attack on Serbia would be an attack on Russia, or if the Germans had been altogether convinced that to invade France would, undoubtedly, involve them in war with England, might not history have taken a happier course?" Remak, The Origins of World War I, p. 89.

98. Jack S. Levy, "The Role of Necessary Conditions in the Outbreak of World War I," in Goertz and Levy, Explaining War and Peace; but for a counterargument, see Trachtenberg, "The Meaning of Mobilization in 1914," pp. 135-136.

99. Bent Bludnikow, "Denmark during the First World War," Iournal of Contemporary History, Vol. 24, No. 4 (October 1989), pp. 683-703, at p. 683.

100. Irmtraud N. Gallhofer and Willem E. Saris, "Strategy Choices of Foreign Policy Decision 
emerged in which less interdependent states chose to enter the war, generally seeking territorial gain, whereas interdependent states preferred to remain neutral, enjoying lucrative commerce. ${ }^{101}$ No exception to the trend, the United States attempted similarly to pursue trade and avoid the conflict for much of the war, until this became impossible under the combined impact of Allied political machinations and German submarine warfare.

\section{Conclusion}

One's understanding of the relationship between interdependence and World War I hinges on the following counterfactual question: If interdependence did not reduce the likelihood of conflict, where would we have expected fighting during the era leading up to the war? As the analysis above suggests, rivalries involving Britain, France, Germany, and Russia were among the most intense of the period and could well have resulted in major contests, as they had in the past and as was expected by many at the time. Yet, war did not begin among the interdependent powers. During the period of greatest commercial expansion, interdependent powers were less likely to go to war with each other, despite having the means and the motives to do so-motives so strong that few students of history would have been surprised if war had in fact broken out on several occasions. Among weakly interdependent powers, in contrast, wars took place frequently, in patterns that seem both timeless and familiar. If interdependence is ineffective, therefore, we must ask ourselves why World War I began among the less interdependent powers and not in the interdependent West.

Just as interdependence is said to increase the incentives for peace by making war more expensive, widening the difference in payoffs between cooperating and not cooperating, so too alliances operate by making war less costly, discouraging aggression or increasing leverage by making it more expensive for allies to fail to intervene in contests involving security partners. It is not clear which effect-the conflict-inhibiting impact of commerce or the conflict-inducing effect of alliance ties-was more intense for the nations of Europe in 1914. We can, however, make the following comparisons. First, the benefits of interdependence varied among countries, ranging from the nearly

Makers: The Netherlands, 1914," Journal of Conflict Resolution, Vol. 23, No. 3 (September 1979), pp. $425-445$.

101. A significant exception is Spain, which, although poor and minimally interdependent, remained neutral. Its decision may have resulted from the fact that it had little to gain from the conflict, being geographically isolated from the main fronts and having already lost all of its colonial possessions (unlike Portugal, which fought to hold on to them). 
autarchic relationships among Balkan powers to the significantly integrated commercial powers. Second, the costs of backing down for European powers almost certainly increased over time, as leaders observed their opponents backing down in previous crises and as alliance ties became increasingly leveraged through tighter commitments. Russia and Germany repeatedly showed a preference for discretion rather than mutual destruction. Yet, tightening alliance ties increasingly vied with crosscutting economic dependencies for the attention and loyalty of national leaders. Only as alliance ties solidified and policymaking increasingly shifted to the less interdependent powers of the Balkans did the interdependent powers appear to become less attentive to the economic consequences of a wider war. Even this risk was discounted by key actors who expected their opponents to crumble under pressure, in part because interdependence increased the cost of war.

The analysis provided here suggests that, in contrast to conventional wisdom, the 1914 crisis is a particularly weak case against commercial liberalism. Economic interdependence significantly affected crisis bargaining during the lead-up to the war. The system of alliances, created to deter opponents and reduce the likelihood of great power war, had an important and unintended consequence that manifested itself through a series of growing crises: it created an incentive for the leaders of the interdependent powers to shift foreign policy discretion away from themselves and toward powers less closely integrated into the economic system. Importantly, this logic implies that under certain conditions states can take actions to avoid conflict that, paradoxically, may make conflict more likely. States that are highly economically integrated may thus have an incentive to integrate militarily with states that are weakly integrated into the global economy. This in turn can produce unintended results. We hope to explore this potential refinement to commercial liberalism in future research.

Our analysis further suggests that conventional methods of inquiry may tend to ignore the kinds of relationships responsible for the outbreak of World War I. Only by looking at the network of ties between highly and weakly interdependent powers can scholars appreciate the role of this structure in the era's crisis behavior. ${ }^{102}$ Focusing solely on economic interdependence paints an in-

102. Paul W. Schroeder makes a similar point about the war: "The disaster in 1914 did not derive therefore from a failure by industrialists to understand the political logic and requirements of economic integration or even the failure or refusal of politicians, military men, various interest groups, and broad publics to appreciate the long-range advantages of peaceful international cooperation over unrestrained competition and conflict. It lay rather in the structure of international politics." Schroeder, "Economic Integration and the European International System in the Era of World War I," American Historical Review, Vol. 98, No. 4 (October 1993), pp. 1130-37, at p. 1134. 
complete and misleading picture, omitting important ways in which the economically developed major powers were connected to less interdependent states through alliances. This level of complexity makes it difficult for scholars to create parsimonious theories, although several scholars have begun to use network theory and methods to do just this. ${ }^{103}$ We hope scholars will build on our argument to refine claims about how economic interdependence interacts with other ties to affect war and peace.

103. Ward, Siverson, and Cao, "Disputes, Democracies, and Dependencies"; Han Dorussen and Hugh Ward, "Trade Networks and the Kantian Peace," Iournal of Peace Research, Vol. 47, No. 1 (January 2010), pp. 29-42; and Yonatan Lupu and Vincent A. Traag, "Trading Communities, the Networked Structure of International Relations, and the Kantian Peace," University of California, 2011. 